Article

\title{
Antimicrobial Activity of Lignin-Derived Polyurethane Coatings Prepared from Unmodified and Demethylated Lignins
}

\author{
Stephanie Elisabeth Klein ${ }^{1,2}$, Abla Alzagameem ${ }^{1,3}$, Jessica Rumpf ${ }^{1,4} \oplus$, Imke Korte ${ }^{4}$, \\ Judith Kreyenschmidt ${ }^{4}$ and Margit Schulze ${ }^{1, *}$ (1) \\ 1 Department of Natural Sciences, Bonn-Rhein-Sieg University of Applied Sciences, von-Liebig-Str. 20, \\ D-53359 Rheinbach, Germany \\ 2 Department of Macromolecular Chemistry, Technical University of Darmstadt, Alarich-Weiß-Straße 4, \\ D-64287 Darmstadt, Germany \\ 3 Faculty of Environment and Natural Sciences, Brandenburg University of Technology BTU \\ Cottbus-Senftenberg, Platz der Deutschen Einheit 1, D-03046 Cottbus, Germany \\ 4 Faculty of Agriculture, Rheinische Friedrich Wilhelms-University Bonn, Katzenburgweg 7-9, \\ D-53115 Bonn, Germany \\ * Correspondence: margit.schulze@h-brs.de; Tel.: +49-2241-865-566; Fax: +49-2241-865-8566
}

Received: 24 May 2019; Accepted: 26 July 2019; Published: 5 August 2019

\begin{abstract}
Due to global ecological and economic challenges that have been correlated to the transition from fossil-based to renewable resources, fundamental studies are being performed worldwide to replace fossil fuel raw materials in plastic production. One aspect of current research is the development of lignin-derived polyols to substitute expensive fossil-based polyol components for polyurethane and polyester production. This article describes the synthesis of bioactive lignin-based polyurethane coatings using unmodified and demethylated Kraft lignins. Demethylation was performed to enhance the reaction selectivity toward polyurethane formation. The antimicrobial activity was tested according to a slightly modified standard test (JIS Z 2801:2010). Besides effects caused by the lignins themselves, triphenylmethane derivatives (brilliant green and crystal violet) were used as additional antimicrobial substances. Results showed increased antimicrobial capacity against Staphylococcus aureus. Furthermore, the coating color could be varied from dark brown to green and blue, respectively.
\end{abstract}

Keywords: antimicrobial activity; brilliant green; crystal violet; demethylation; lignin; polyurethane coatings; triphenylmethane dyes

\section{Introduction}

Lignin, the most abundant natural resource next to cellulose and hemicellulose [1-4] contains various functional groups that provide active sites for chemical modification such as polarity adjustment to enhance the compatibility of lignin with other polymeric matrices in lignin/polymer composites [4,5] or to improve antioxidant properties [6-11]. Furthermore, studies reported lignin-derived encapsulation of various drugs for biomedical and agricultural applications. Richter et al. reported the encapsulation of silver nanoparticles in lignin-coated polymers [12]. Gregorova et al. studied the encapsulation of lignin nanoparticles in polyethylene films (Björkman lignin from beech wood flour) [13]. In other studies, the delivery of Resveratrol ${ }^{\circledR}$ [14], the controlled release of Avermectin ${ }^{\circledR}$ [15], lignin-polyurea microcapsules with anti-photolysis and sustained-release performances [16], montmorillonite-lignin hybrid hydrogel as super-sorbent for dye removal from wastewater [17], cellulose-lignin hydrogels and their controlled release of polyphenols [18], lignin-stimulated protection of polypropylene films 
and DNA in cells of mice against oxidation damage [19] have been tested. Gao [20] and Bshena [21] studied the antimicrobial activity of various textiles, using lignin incorporated into polyethylene films and applied in the finishing processes. For textiles, there are special requirements such as non-toxicity to the consumer, namely cytotoxicity, allergy or irritation and sensitization. In other recent studies, lignosulfonic acid is reported to exhibit broad-spectrum anti-HIV (human immunodeficiency virus) and anti-HSV (herpes simplex virus) properties [22,23]. Thus, Qiu investigated the anti-HIV-1 activity-potential of lignosulfonates as a microbicide to prevent HIV-1 sexual transmission [23]. Another recently reported study revealed that the antimicrobial capacity of lignin correlates with the phenolic components, specifically the side chain structure and the nature of further functional groups [24]. Typically, the presence of a double bond in $\alpha, \beta$ positions of the side chain and a methyl group in the $\gamma$ position grants the phenolic fragments with the most potency against microorganisms. However, none of the hitherto published studies included the investigation of the antibacterial activity of lignin when included in polymeric matrices.

Unmodified lignin is widely studied as a component for polymer production with a focus on phenol-formaldehyde resins and polyurethanes (PUs) [25], where lignin is used as polyol substitute due to the high amount of hydroxyl groups resulting in high crosslinking densities and variable mechanical properties [26-28]. In previous studies, lignin-derived polyurethane coatings have been prepared using Kraft lignin isolated at room temperature from aqueous media (black liquor) at different $\mathrm{pH}$ values [29]. In addition, their antioxidative activity has been investigated using the Folin-Ciocalteu (FC) assay [30]. Although lignin contains many functionalities, they are often difficult to access due to rather strong steric hindrance. So far, various procedures have been explored to incorporate more $\mathrm{OH}$ groups into the lignin structure including hydroxymethylation, phenolation, demethylation, oxidation and reduction [31]. These modifications have been studied primarily in conjunction with phenol-formaldehyde (PF) resins or PU research using lignin as a replacement for fossil-based phenols and polyols [32].

In 2016, Li et al. reported using demethylation to enhance the chemical reactivity at atmospheric pressure to produce fast curing phenolic resins [33]. Another possibility for lignin demethylation is an enzymatically catalyzed reaction using fungi (i.e., white and brown rot fungi) or bacteria (i.e., Pseudomonas, Sphingomonas). Mainly laccase was investigated, which oxidizes the guaiacyl into catechol units [34]. Industrially, demethylated lignin is recovered as a byproduct in dimethylsulfoxide (DMSO) production. For this purpose, black liquor is mixed with molten sulfur at about $230{ }^{\circ} \mathrm{C}$. Two methyl groups are transferred from the lignin to the sulfur, forming dimethyl sulfide, which is oxidized to DMSO with nitrogen dioxide. Based on this process, Kraft lignin was demethylated with sulfur at 225 to $235^{\circ} \mathrm{C}$ under high pressure and successfully increased its reactivity for the synthesis of phenol-formaldehyde (PF) resins [34]. Sulfur and halogen compounds are also used as nucleophiles for the chemical demethylation of lignin. For example, Chung and Washburn have demethylated softwood Kraft lignin with hydrobromic acid under the catalytic action of hexadecyltributylphosphonium bromide at $115^{\circ} \mathrm{C}$ for $20 \mathrm{~h}$, resulting in an increase in the $\mathrm{OH}$ content of $28 \%$ [35]. PU foams synthesized from the modified Kraft lignins showed a higher compressive strength than conventional ones [36,37]. Song et al. used the same method for white straw alkali lignin, with results that showed a significant increase in the total hydroxy content of demethylated lignin [38] when samples were explored for the synthesis of bio-based PF resins by demethylations with sulfur-containing compounds (sulfur, n-dodecyl mercaptan, sodium hydrogen sulfide and sodium sulfite). Here, soda lignin was heated with the reagent for $1 \mathrm{~h}$ at $90^{\circ} \mathrm{C}$. This research aimed to provide a cost-effective and efficient method for the chemical demethylation of lignin. The best results in terms of an increase in $\mathrm{OH}$ content and use for PF resins was the sample demethylated with $\mathrm{Na}_{2} \mathrm{SO}_{3}$. Other authors used $\mathrm{Na}_{2} \mathrm{SO}_{3}$ for demethylation performed under high-pressure reactors [39] or under reflux [15,40]. Podschun et al. chose a different approach in which organosolv lignin was demethylated under microwave radiation [41]. 
The antimicrobial properties of various dyes, in particular triphenylmethane (TPM) derivatives such as malachite green and crystal violet, have been studied since their first successful application as bioactive additives more than a hundred years ago (Figure 1, Table 1).

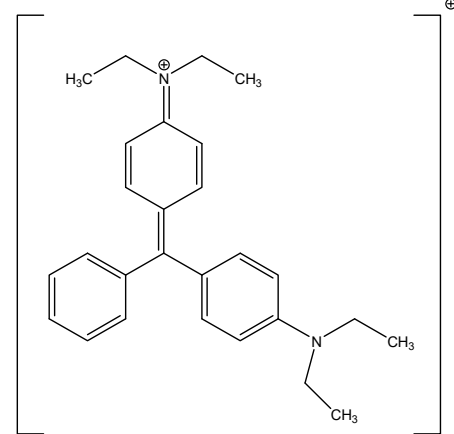

(a)

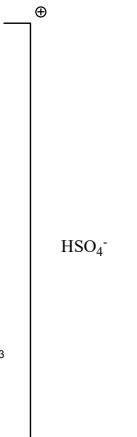

L

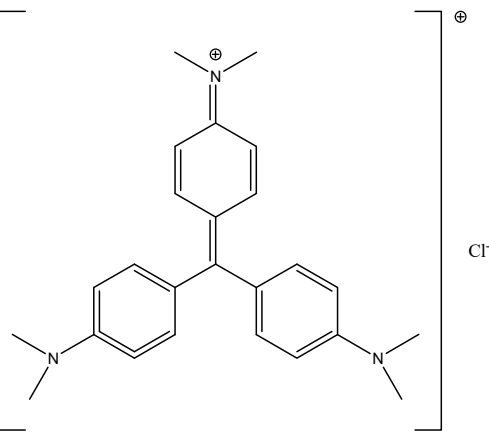

(b)

Figure 1. Molecular structure of (a) brilliant green and (b) crystal violet (see also Table 1).

In 1891, methylene blue, another TPM derivative was discovered by Paul Ehrlich to be efficient in malaria treatment, a few years later followed by the discovery of the antiseptic capacity of brilliant green (BG) [42-44]. For many years, malachite green was one of the most frequently used disinfectants in aquaculture due to its fungicidal effects. Due to the discovery of antibiotics and biocide polymers, antimicrobial dyes have not only been displaced in biomedicine but also other applications. Bolous et al. intensively studied the mechanisms of antimicrobial effects [45,46]. In detail, it was reported that the evidence to link the antimicrobial properties of TPM dyes, especially brilliant green, to the activity of mechanosensitive ion channel (MIC) of large conductance, which is known to be highly specific and ubiquitous in various bacterial species [47]. In 2012, Vilela et al. reported a study using methylene blue (MB) and malachite green photosensitizer microbial reduction of Staphylococcus aureus by synthesizing biofilms with it. The best results showed microbial reduction with $3000 \mu \mathrm{M}$ of malachite green with a microbial reduction of $1.6-4.0 \log _{10}$ [48]. In oral cavities, biofilm formation is considered to cause resistance to antimicrobial agents. Photodynamic therapies using phenothiazinic photosensitizers first confirmed the antimicrobial effect in biofilms. Malachite green was then compared with the phenothiazinic photosensitizers (methylene blue and toluidine blue) on Staphylococcus aureus and Escherichia coli biofilms. Noimark et al. reported the synthesis of modified photobactericidal silicones for medical applications. In detail, crystal violet and/or methylene blue were incorporated into the silicone bulk and gold nanoparticles were coated using a dipping method. The polymers showed good photostability, the photobactericidal activity was determined against Staphylococcus epidermidis and Escherichia coli. The results showed that these multi-dye-nanogold-polymers exhibit strong photobactericidal activity both under light and dark conditions [49]. Bartoszewicz et al. filed a patent claiming lubricious antimicrobial coatings containing silver, pyrrolidone carboxylic acid (PCA) and a TPM dye (malachite green). The coating composition of the invention provides photostability to the silver ions contained therein and is hydrophilic and antimicrobial [50]. In 2016, Santos et al. comprehensively reviewed various classes of antimicrobial polymers and discussed their bioactivity mechanisms including biocidal activity, antifungal and antibacterial capacity against numerous microorganisms (i.e., gram positive and gram negative bacteria and fungi) [51]. Table 1 summarizes literature reporting the antimicrobial activity of lignins and triphenylmethane derivatives such as malachite green, brilliant green, methylene blue and crystal violet. 
Table 1. Literature studies regarding antimicrobial activity of lignins and triphenylmethane derivatives (i.e., malachite green, brilliant green, methylene blue and crystal violet).

\begin{tabular}{|c|c|c|c|c|}
\hline Sample Composition & $\begin{array}{l}\text { Studied Activity (Antibacterial, } \\
\text { Antifungal) }\end{array}$ & $\begin{array}{l}\text { Microorganisms (Bacteria, } \\
\text { Fungi) }\end{array}$ & Results & References \\
\hline Triphenylmethane (TPM) dyes & $\begin{array}{l}\text { Mechanistic studies of the } \\
\text { antimicrobial effects of } \\
\text { triphenylmethanes (crystal violet, } \\
\text { methylene blue, malachite green, } \\
\text { brilliant green). }\end{array}$ & $\begin{array}{l}\text { Various gram positive and gram } \\
\text { negative bacteria }\end{array}$ & $\begin{array}{l}\text { Evidence to link the antimicrobial properties of TPM } \\
\text { dyes, especially brilliant green, to the activity of } \\
\text { mechanosensitive ion channel (MIC) of large } \\
\text { conductance, known to be highly specific/ubiquitous in } \\
\text { various bacterial species. }\end{array}$ & Bolous et al. [45-47] \\
\hline $\begin{array}{l}\text { TPM dyes (i.e., methylene blue, } \\
\text { malachite green) used as } \\
\text { photosensitizer for acrylic resins }\end{array}$ & Microbial reduction of biofilms. & S. aureus & $\begin{array}{l}\text { Best microbial reduction with } 3000 \mu \mathrm{M} \text { malachite green } \\
\text { with microbial reduction of } 1.6-4.0 \log _{10} \text {. }\end{array}$ & Vilela et al. [48] \\
\hline $\begin{array}{l}\text { TPM-based antimicrobial } \\
\text { surfaces }\end{array}$ & $\begin{array}{l}\text { Antimicrobial effects of crystal violet } \\
\text { and methylene blue. }\end{array}$ & $\begin{array}{l}\text { S. epidermidis (RP62a) and E. coli } \\
\text { (NCTC 25522) }\end{array}$ & $\begin{array}{l}\text { Light-activated antimicrobial surfaces with enhanced } \\
\text { efficacy induced by a dark-activated mechanism. }\end{array}$ & Noimark et al. [49] \\
\hline $\begin{array}{l}\text { TPM-based coating additives } \\
\text { (i.e., brilliant green, crystal } \\
\text { violet) for polymeric substrates } \\
\text { including PU }\end{array}$ & $\begin{array}{l}\text { Antimicrobial activity of photo-stable } \\
\text { composition used for coating a variety } \\
\text { of medical materials. }\end{array}$ & Not specified & $\begin{array}{c}\text { The coating composition comprising silver and TPM } \\
\text { dyes (malachite green) provided photostability to the } \\
\text { silver ions and antimicrobial activity. }\end{array}$ & $\begin{array}{l}\text { Bartoszewicz et al. } \\
\text { WO 2009/015476 Al [50] }\end{array}$ \\
\hline Antimicrobial polymers & $\begin{array}{l}\text { Bioactive polymers including biocidal } \\
\text { activity, antifungal and antibacterial } \\
\text { capacity. }\end{array}$ & $\begin{array}{l}\text { Various gram positive and gram } \\
\text { negative bacteria }\end{array}$ & $\begin{array}{l}\text { Comprehensive review discussing different mechanisms } \\
\text { regarding antimicrobial effects in polymer materials. }\end{array}$ & Santos et al. 2016 [51] \\
\hline $\begin{array}{l}\text { Lignin/HPMC and } \\
\text { HPMC/lignin/chitosan } \\
\text { composites }\end{array}$ & Antibacterial effects. & $\begin{array}{l}\text { E. coli and S. aureus, } \\
\text { B. thermosphacta and } \\
\text { P. fluorescens }\end{array}$ & $\begin{array}{l}\text { Testing the films against spoilage bacteria that grow at } \\
\text { low temperatures revealed the activity of the } 30 \% \\
\text { addition on HPMC/lignin against B. thermosphacta and } \\
\text { P. fluorescens. HPMC/lignin/chitosan films ( } 5 \% \text { lignin) } \\
\text { showed activity against both B. thermosphacta and } \\
\text { P. fluorescens. }\end{array}$ & Alzagameem et al. 2019 [52] \\
\hline $\begin{array}{c}\text { Cellulose and lignin effects on } \\
\text { disintegration, antimicrobial } \\
\text { and antioxidant properties of } \\
\text { PLA active films }\end{array}$ & $\begin{array}{l}\text { Antimicrobial, antioxidant and } \\
\text { disintegrability activities }\end{array}$ & $\begin{array}{l}\text { Gram negative bacteria: } \\
\text { Xanthomonas axonopodis pv. } \\
\text { vesicatoria and Xanthomonas } \\
\text { arboricola pv. pruni }\end{array}$ & $\begin{array}{l}\text { Inhibition capacity for Gram negative bacteria } \\
\text { (Xanthomonas axonopodis pv. vesicatoria and Xanthomonas } \\
\text { arboricola pv. pruni) for lignin-modified PLA films. }\end{array}$ & Yang et al. 2016 [53] \\
\hline $\begin{array}{l}\text { Lignin derivatives (epoxides, } \\
\text { esters, ether) }\end{array}$ & $\begin{array}{c}\text { Antimicrobial activity of chemically } \\
\text { modified lignins (by acetylation, } \\
\text { epoxidation and } \\
\text { hydroxymethylation reactions). }\end{array}$ & Bacillus aryabhattai and Klebsiella & $\begin{array}{l}\text { Epoxy/lignin was found to be the most effective } \\
\text { antibacterial among modified lignin with minimum } \\
\text { inhibitory concentration of } 90 \text { and } 200 \mu \mathrm{g} / \text { disc. }\end{array}$ & Kaur et al. 2017 [54] \\
\hline Lignin for benign encapsulation & $\begin{array}{l}\text { Antimicrobial activity of nanoparticles } \\
\text { coated with LignoBoostTM softwood } \\
\text { Kraft lignin. }\end{array}$ & $\begin{array}{c}\text { E. coli and } \\
\text { Pseudomonas aeruginosa }\end{array}$ & $\begin{array}{l}\text { Nanoparticle flash precipitation with subsequent silver } \\
\text { ion infusion and polyelectrolyte coating including lignin. }\end{array}$ & Richter et al. 2015 [12] \\
\hline $\begin{array}{c}\text { Antibacterial } \\
\text { lignin-polyethylene (PE) }\end{array}$ & $\begin{array}{l}\text { Lignin nanoparticles embedded in } \\
\text { polyethylene films (Björkman lignin } \\
\text { from beech wood flour). }\end{array}$ & E. coli and S. aureus & $\begin{array}{l}\text { Lignin particles exhibit antibacterial effect against } E \text {. coli } \\
\text { and S. aureus in the same order of magnitude as other } \\
\text { antibacterial agents such as Bronopol }{ }^{\circledR} \text { and } \\
\text { Chlorohexidine }{ }^{\circledR} \text {. }\end{array}$ & Gregorova et al. 2011 [13] \\
\hline
\end{tabular}


In a recently published study, chitosan/hydroxypropylmethylcellulose (HPMC) composites with varying ratio up to $30 \%$ of Kraft lignins (isolated from black liquor and purified via solvent extraction) were prepared and tested against spoilage bacteria that grow at low temperatures. The results revealed the activity against both $B$. thermosphacta and $P$. fluorescens for samples with $30 \%$ lignin. In HPMC/lignin/chitosan films, the $5 \%$ addition exhibited activity against both $B$. thermosphacta and P. fluorescens [52]. Currently, these lignin-derived composites are studied regarding their applications as scaffold component for mesenchymal stem cell differentiation and bone regeneration [55]. To do so, lignin as feedstock component has to be specified including protocols for quality control using novel chemometric data analysis methods [56,57].

In the present study, lignins isolated from black liquor at different $\mathrm{pH}$ values were used to explore the potential of these compounds as an antimicrobial component in polyurethane coatings. First, the extraction conditions that favored high lignin yields were optimized. Unmodified and demethylated lignins were used to prepare the lignin-polyurethane (LPU) coatings. The last part of the study aimed to correlate the antimicrobial properties with extraction conditions (i.e., $\mathrm{pH}$ value) and molecular structures (unmodified versus demethylated lignins). Furthermore, the influence of additional antimicrobial dyes (brilliant green and crystal violet) on the LPU coating bioactivity, color and morphology was studied.

\section{Materials and Methods}

\subsection{Extraction of Kraft Lignin (KL) and Organosolv Lignin (OL)}

The Kraft lignin (KL) was extracted through the acidic precipitation from black liquor according to a procedure reported by Garcia et al. [58]. First, about $450 \mathrm{~mL}$ of black liquor was filtered with a vacuum filter. The filter cake was rejected. Of the filtrate, $400 \mathrm{~mL}$ was heated to $50-60^{\circ} \mathrm{C}$. Sulfuric acid ( $160 \mathrm{~mL}, 25 \mathrm{vol} . \%)$ was added while stirring. The mixture was stirred for another hour at room temperature and then vacuum filtered. The filter cake was washed with distilled water and sulfuric acid ( $25 \mathrm{vol} . \%)$ until the requested $\mathrm{pH}$ value was reached ( $\mathrm{pH} 2$ to $\mathrm{pH}$ ). Finally, the precipitated lignin was dried in a freeze dryer for $48 \mathrm{~h}$. The organosolv lignin (OL) was isolated according to a procedure recently reported [10].

\subsection{Synthesis of Demethylated Kraft Lignin}

For the demethylation, a procedure reported by Li et al. was used and slightly modified [33]. The sample $(1 \mathrm{~g}), 0.1 \mathrm{~g}$ of $\mathrm{Na}_{2} \mathrm{SO}_{3}$ as the demethylating reagent and $6 \mathrm{~g}$ of $2.5 \mathrm{~mol} \mathrm{NaOH}$ solution were introduced into a $15 \mathrm{~mL}$ rolled rim glass on an analytical balance and homogenized. The solution was heated with stirring to 90 or $72{ }^{\circ} \mathrm{C}$ and stirred for $1 \mathrm{~h}$ at this temperature. After cooling to room temperature (RT), the $\mathrm{pH}$ was adjusted to $\mathrm{pH} 2$ by means of $1 \% \mathrm{HCl}$. The demethylated lignin precipitated as a brown solid. The suspension was transferred to a $45 \mathrm{~mL}$ tube and centrifuged for $10 \mathrm{~min}$ at $3000 \mathrm{rpm}$ to separate the demethylated lignin from the aqueous solution. The lignin was washed with distilled water and the $\mathrm{pH}$ adjusted to $\mathrm{pH} 7$ with 2.5 molar $\mathrm{NaOH}$ solution. It was again centrifuged (for $30 \mathrm{~min}$ at $4000 \mathrm{rpm}$ ) to separate the aqueous phase from the demethylated lignin. The product was first stored at $40^{\circ} \mathrm{C}$ in a drying oven and then freeze-dried at $80{ }^{\circ} \mathrm{C}$ and 0.10 mbar. Subsequently, the samples were homogenized and transferred for storage in rolled edge glasses, which were closed with snap lids. Furthermore, the samples were protected against UV radiation.

\subsection{Size Exclusion Chromatography}

Size exclusion chromatography was used to determine the number-average $\left(M_{n}\right)$ and weight-average $\left(M_{\mathrm{w}}\right)$ molecular weights of lignins and their polydispersities, analogue to recently reported methods $[29,30]$. A PSS SECurity ${ }^{2}$ GPC System was used with tetrahydrofuran as the mobile phase, a run time of $30 \mathrm{~min}$ and an injection volume of $100 \mu \mathrm{L}$. The system was calibrated using polystyrene standards at different molecular weights. 


\subsection{Determination of Hydroxyl Groups}

The content of hydroxyl groups was determined via two different methods. ISO 14900:2001(E) developed for polyether polyols with steric hindrance was recently reported [29]. Shortly, each lignin sample was boiled under reflux in $25 \mathrm{~mL}$ of acetylation reagent solution with a blank sample simultaneously under the same conditions. After three hours at reflux, the flasks were left to cool down to room temperature. Twenty-five milliliters of sample and blank, respectively, were filled up with water to $100 \mathrm{~mL}$ and were titrated with sodium hydroxide $(0.5 \mathrm{M})$. The split up of the acetylated samples and blanks allowed a triple determination via titration. Different amounts of sample and blank were needed. The differences were used to determine the total hydroxyl content.

\subsection{Antibacterial Activity of Lignin}

The antimicrobial activity of the lignin powders samples was analyzed in a quantitative way by modifying the test for antimicrobial activity and efficacy (JIS Z 2801:2010) of liquid samples [59]. The JIS is based on a comparison of bacteria counts in saline solution on reference and sample materials after a defined incubation temperature and time. Staphylococcus aureus (DSM No. 799) was applied as the test organism. The inoculum was prepared in the same way as described above. According to the McFarland-standard the inoculum was adjusted in physiological saline solution with tryptone (Blank, Vörstetten, Germany; VWR International, Darmstadt, Germany) to a concentration of

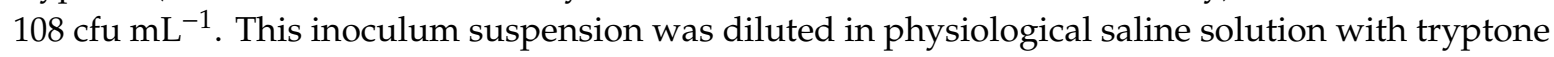
(Blank, Vörstetten, Germany; VWR International, Darmstadt, Germany) to a final concentration of $105 \mathrm{cfu} \mathrm{mL}^{-1}$. Lignin powder was added into tubes with $5 \mathrm{~mL}$ physiological saline solution with tryptone to a final concentration of $0.1,0.01$ and $0.001 \mathrm{~g} \mathrm{~mL}^{-1}$. Each tube was inoculated with $50 \mu \mathrm{L}$ of the inoculum. The same measurements were done in nutrient broth instead of physiological saline solution. The measurements were carried out in triplicates.

The inoculum $(1 \mathrm{~mL})$ was incubated at $37^{\circ} \mathrm{C}$ for $24 \mathrm{~h}$ in a mixture of $9 \mathrm{~mL}$ nutrient broth (Merck $\mathrm{KGaA}$, Darmstadt, Germany) and $1 \mathrm{~mL}$ of sample or reference. Afterwards viable counts were determined by counting the colonies on plate-count agar after incubation at $37^{\circ} \mathrm{C}$ for $24 \mathrm{~h}$.

The value of antimicrobial activity was calculated by subtracting the logarithmic value of viable counts of the sample from the logarithmic value of reference material after inoculation and incubation:

$$
\log _{10}-\text { reduction }=\log _{10}\left(\frac{c_{\text {gew }}(\text { reference })}{c_{\text {gew }}(\text { sample })}\right)
$$

where as $c_{\text {gew }}$ (reference $)=$ arithmetic mean of bacterial counts of reference $24 \mathrm{~h}$ after inoculation, and $c_{\text {gew }}($ sample $)=$ arithmetic mean of bacterial counts of sample material $24 \mathrm{~h}$ after inoculation. According to the JIS Z 2801:2010 a material can be characterized as antimicrobial, if the calculated $\log _{10}$-reduction is $\geq 2.0$ after $24 \mathrm{~h}$ at $37^{\circ} \mathrm{C}[59]$.

\subsection{Hemmhoff Test}

The antimicrobial activity of the lignin was tested according to the disk diffusion test of the National Committee for Clinical Laboratory Standards (NCCLS) standard method. The disk diffusion test is based on the diffusion of the sampling material in agar. If the bacterium is sensitive to the tested substance, the growth of the bacterium is inhibited and a visible inhibition zone arises. The inhibition zone is the defined area between the punched out area and the beginning of the grown bacterium. If there is no inhibition zone, the bacterium is not sensitive to the tested substance.

Staphylococcus aureus (DSM No. 799) was used as a test organism. The inoculum was prepared by transferring a frozen culture to $10 \mathrm{~mL}$ of nutrient broth (Merck KGaA, Darmstadt, Germany). The nutrient broth with the inoculum was incubated at $37^{\circ} \mathrm{C}$ for $24 \mathrm{~h}$. According to the McFarland-standard the inoculum was adjusted in physiological saline solution with tryptone (Blank, Vörstetten, Germany; VWR International, Darmstadt, Germany) to a final concentration 
of $108 \mathrm{cfu} \mathrm{mL}^{-1}$. In each Petri dish (Sarstedt AG, Nümbrecht, Germany) $100 \mu \mathrm{L}$ of the inoculum was spatulated on Mueller-Hinton agar (VWR International, Darmstadt, Germany) which were impregnated with the different lignins and blank filter papers as references and were put on the inoculated agar plates.

The agar plates were incubated at $37^{\circ} \mathrm{C}$ for $24 \mathrm{~h}$. Afterwards, the diameter of the inhibition zone was measured with a digital caliper (Traceable Digital Caliper 6, VWR International, Darmstadt, Germany).

\subsection{Synthesis of Lignin-Based Polyurethane Coatings}

PEG400 was obtained from Sigma-Aldrich (Steinheim, Germany). 4,4-Diphenylmethane diisocyanate (MDI, for synthesis) was purchased from Merck in Darmstadt and triethylamine (TEA, for synthesis) was received from Carl Roth $\mathrm{GmbH}$ in Karlsruhe. All chemicals were used without further purification. PEG400 was mixed with lignin to obtain $1 \mathrm{~g}$ of polyol blend. Coatings prepared from lignins isolated at different $\mathrm{pH}$ values were produced analogously to the previously described procedure, with the MDI amount adapted to the hydroxyl number of the lignin and the resulting polyol blend. Lignin-based PU coatings were prepared using unmodified and demethylated lignins, respectively, and 4,4-diphenylmethandiisocyanate (MDI). The NCO:OH ratio was 1.7. The calculation was performed according to literature reference $[60,61]$ :

$$
\frac{\mathrm{NCO}}{\mathrm{OH}}=\frac{w_{\mathrm{MDI}} \times[\mathrm{NCO}]_{\mathrm{MDI}}}{w_{\mathrm{L}} \times[\mathrm{OH}]_{\mathrm{L}}+w_{\mathrm{P}} \times[\mathrm{OH}]_{\mathrm{P}}}
$$

where $w_{\mathrm{MDI}}, w_{\mathrm{L}}$ and $w_{\mathrm{P}}$ are the weights $(\mathrm{g})$ of $\mathrm{MDI}$, lignin and polyol, respectively. [NCO $]_{\mathrm{MDI}}$ is the molar content of isocyanate groups in MDI, $8.0 \mathrm{mmol} / \mathrm{g}$ for $4,4^{\prime}-\mathrm{MDI}$. $[\mathrm{OH}]_{\mathrm{L}}$ and $[\mathrm{OH}]_{\mathrm{P}}$ are the molar contents of total hydroxyl groups in the lignin and the polyol, respectively. Masses of lignin and polyol were kept constant. Thus, $1 \mathrm{~g}$ of lignin was dissolved in $6 \mathrm{~mL}$ THF under constant stirring. MDI was added and the mixture was transferred on a polyethylene (PE) transparency and dried for $1 \mathrm{~h}$ at room temperature. Finally, the pre-films were cured at $37^{\circ} \mathrm{C}$ for $3 \mathrm{~h}$ to obtain the final lignin PU films. The synthesis of lignin-modified PU coatings with brilliant green (BG) and crystal violet (CV) followed the same procedure, using $0.8 \%(w / v)$ of the corresponding triphenylmethane derivative.

Analogously, $1 \mathrm{~g}$ of demethylated lignin was dissolved in $6 \mathrm{~mL}$ of THF under constant stirring to prepare the LPU coatings. MDI was added and the mixture was transferred onto a PE-transparency and dried for $1 \mathrm{~h}$ at room temperature. Finally, the pre-films were cured at $35^{\circ} \mathrm{C}$ for $3 \mathrm{~h}$ to obtain the final lignin-derived PU films.

\subsection{Antimicrobial Activity of the LPU Coatings}

The antimicrobial activity of the coatings was analyzed based on the Japanese Industrial Standard (JIS) Z 2801:2010 [59]. The JIS is based on the comparison of bacteria counts on sample coating/surface and reference material after a defined storage temperature and time $\left(35^{\circ} \mathrm{C}, 24 \mathrm{~h}\right)$. The reduction of bacteria counts were calculated and represented as $\log _{10}$-reduction. The $\log _{10}$-reduction is a measure for the antimicrobial activity and effectiveness of the coatings. According to the JIS a material is called antimicrobial when the $\log _{10}$-reduction is $\geq 2 \log _{10}$.

Staphylococcus aureus (DSM No. 799) and Listeria monocytogenes were used as test organisms. The inoculum was prepared by transferring a frozen culture to $10 \mathrm{~mL}$ of nutrient broth (Merck KGaA, Darmstadt, Germany). The nutrient broth with the inoculum was incubated at $37^{\circ} \mathrm{C}$ for $24 \mathrm{~h}$. According to the McFarland-standard the inoculum was adjusted in physiological saline solution with tryptone (Blank, Vörstetten, Germany; VWR International, Darmstadt, Germany) to a final concentration of $108 \mathrm{cfu} \mathrm{mL}^{-1}$. This inoculum suspension was diluted in physiological saline solution with tryptone to a final concentration of $105 \mathrm{cfu} \mathrm{mL}^{-1}$.

The coatings and references were inoculated with $400 \mu \mathrm{L}$ of the inoculum suspension. To enlarge the contact area of the coatings with the inoculum, the inoculum was covered with a sterile foil (Interscience, 
Saint-Nom-la-Bretèche, France). The plates were incubated at $37^{\circ} \mathrm{C}$ for $24 \mathrm{~h}$. After incubation the inoculated suspension was washed out with $10 \mathrm{~mL}$ soybean casein lecithin polysorbate 80 broth (SCDLP) solution (Merck KGaA, Darmstadt, Germany). This served as the first solution stage and was used for further decimal solution series. The bacteria counts were determined by using the drop-plate-technique and counting the colonies on plate-count agar (Merck KGaA, Darmstadt, Germany) after incubation at $37^{\circ} \mathrm{C}$ for $24 \mathrm{~h}$.

The value of antimicrobial activity was calculated by subtracting the logarithmic value of viable counts of the sample from the logarithmic value of reference material after inoculation and incubation:

$$
\log _{10}-\text { reduction }=\log _{10}\left(\frac{c_{\text {gew }}(\text { reference })}{c_{\text {gew }}(\text { sample })}\right)
$$

where $c_{\text {gew }}($ reference $)=$ arithmetic mean of bacterial counts of reference $24 \mathrm{~h}$ after inoculation, and $c_{\text {gew }}($ sample $)=$ arithmetic mean of bacterial counts of sample material $24 \mathrm{~h}$ after inoculation. According to the JIS Z 2801:2010 a material can be characterized as antimicrobial, if the calculated $\log _{10}$-reduction is $\geq 2.0$ after $24 \mathrm{~h}$ at $37^{\circ} \mathrm{C}$.

\subsection{Thermogravimetric Analysis}

TGA measurements were performed with about $10 \mathrm{mg}$ of lignin using a Netzsch (Selb, Germany) TGA $209 \mathrm{~F} 1$ with a heating rate of $10^{\circ} \mathrm{C} \mathrm{min}^{-1}$ under a nitrogen atmosphere. The temperature ranged from ambient to $800^{\circ} \mathrm{C}$.

\subsection{Optical Contact Angle}

Static optical contact angle (OCA) measurements were performed on the PU films at room temperature using an OCA device equipped with a charge-coupled device (CCD) photocamera (DataPhysics Instruments, Filderstadt, Germany). A $40 \mu \mathrm{L}$ volume of distilled water was used to dispense liquid droplets.

\subsection{Scanning Electron Microscopy}

Scanning electron microscopy (SEM) from ThermoFischer was combined with X-ray analysis (SEM-EDX). Characterization of the texture, phases and the thin LPU layer were determined by SEM-EDX microscopy using an ESEM Quanta FEG 250 FEI with Apollo XL30 EDX (Thermo Fisher Scientific Inc., Huntsville, AL, USA).

\section{Results and Discussion}

\subsection{Antibacterial Activity of Kraft Lignin}

Kraft lignins were demethylated (DL) and characterized regarding their molecular weight and hydroxyl content (Table 2). In addition, Table 2 shows Kraft lignins isolated at different $\mathrm{pH}$ values [29].

Studies of the antimicrobial activity were performed following procedures reported to investigate intrinsically antimicrobial polymers based on poly((tertbutyl-amino)-methyl-styrene) [62-66] and coatings based on HPMC/lignin/chitosan [52]. Two different nutritions were used: sodium chloride $(\mathrm{NaCl})$ and physiological saline solution (NB) of different concentrations (Figure 2).

Results for both solutions ( $\mathrm{NaCl}, \mathrm{NB}$ ) clearly showed an increase in antimicrobial activity against Staphylococcus aureus for the lignins isolated at different $\mathrm{pH}$ values ( $\mathrm{pH} 2$ to $\mathrm{pH} 5$ ) with the highest activity $\left(\log _{10}\right.$ reduction of 7.0$)$ for the $\mathrm{pH} 5$ samples. This tendency could also be confirmed for the corresponding LPU coatings prepared from the different lignin samples (see next paragraph). Due to the measurement procedure, the study started using the highest concentrations $(0.1 \mathrm{~mol} / \mathrm{L})$, then the concentration decreased down to $0.001 \mathrm{~mol} / \mathrm{L}$. Obviously, the lowest concentrations were sufficient for the observed antimicrobial effects. Similar results could be observed for the HPMC/lignin coatings 
recently reported [52] and also for organosolv lignins (not yet published). Further studies are required to clarify the correlation of concentration and antimicrobial activity.

Table 2. Weight-average $\left(M_{\mathrm{w}}\right)$ and number-average $\left(M_{\mathrm{n}}\right)$ molecular weight and polydispersity (PDI) obtained by gel permeation chromatography (GPC) measurements, and $\mathrm{OH}$ content according to ISO 14900 for demethylated lignins (DL) and Kraft lignins isolated at different $\mathrm{pH}$ values [29].

\begin{tabular}{|c|c|c|c|c|c|c|}
\hline Lignin & $M_{\mathrm{w}}(\mathrm{g} / \mathrm{mol})$ & $M_{\mathrm{n}}(\mathrm{g} / \mathrm{mol})$ & PDI & \multicolumn{2}{|c|}{ OH content (ISO 14900) } & Reference \\
\hline & & & & & & \\
\hline $\mathrm{pH} 2$ & 1879 & 574 & 3.3 & 2.67 & 150 & [29] \\
\hline $\mathrm{pH} 3$ & 1732 & 538 & 3.2 & 4.48 & 251 & [29] \\
\hline $\mathrm{pH} 4$ & 1570 & 441 & 3.6 & 5.02 & 282 & [29] \\
\hline pH5 & 1502 & 490 & 3.0 & 5.34 & 300 & [29] \\
\hline DL-pH2 & 5417 & 1299 & 4.2 & 4.75 & 266 & - \\
\hline DL-pH3 & 5461 & 1318 & 4.1 & 4.00 & 224 & - \\
\hline DL-pH4 & 5522 & 1335 & 4.1 & 5.51 & 309 & - \\
\hline DL-pH5 & 5610 & 1347 & 4.2 & 4.80 & 269 & _- \\
\hline
\end{tabular}

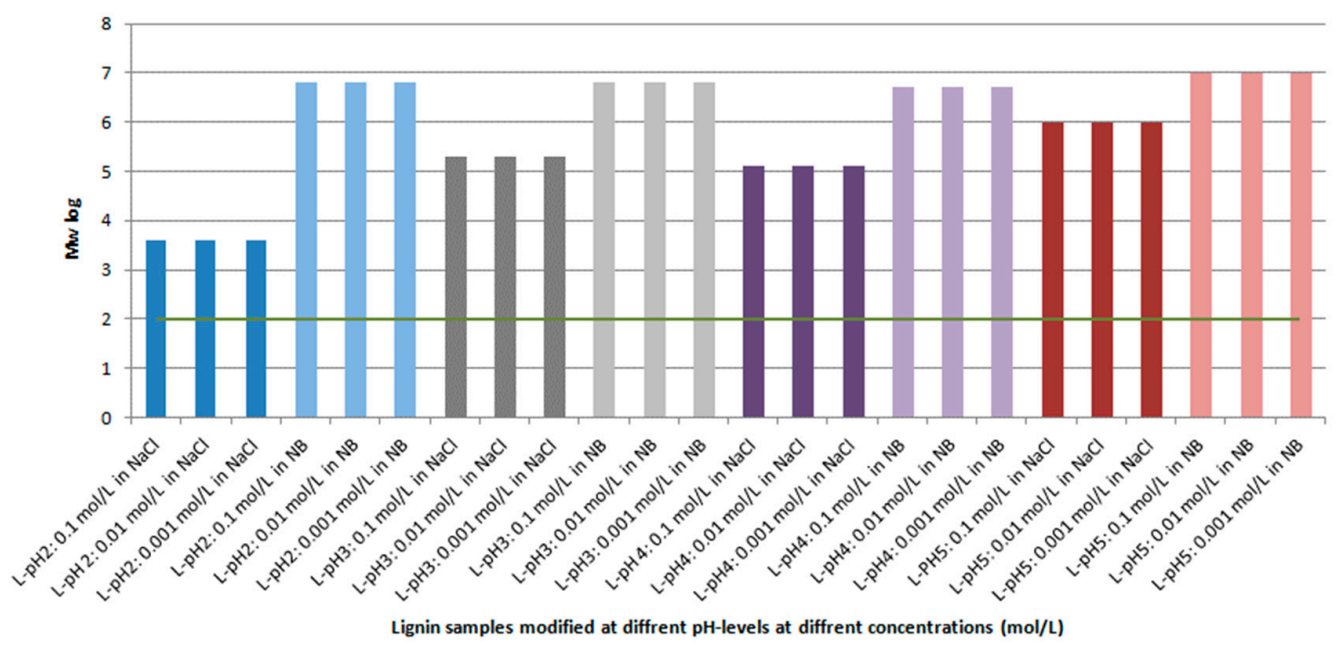

Figure 2. Antimicrobial activity of unmodified Kraft lignins isolated at different $\mathrm{pH}$ levels (varying from 2 to 5). Activity tested against Staphylococcus aureus in $\mathrm{NaCl}$ and physiological saline solution (NB)), respectively, in concentrations ranging between $0.1-0.001 \mathrm{~mol} / \mathrm{L}$.

\subsection{Antibacterial Activity of LPU Coatings}

For the comparability of subsequent investigations, first the antimicrobial effect on different reference surfaces was tested according to Japanese Industrial Standard Z 2801:2000 [59]. The results are shown in Table 3 and Figure 3.

Table 3. Results of antimicrobial activity of different reference systems surfaces against S. aureus.

\begin{tabular}{ccc}
\hline Reference Systems (blank) & Kbe $\mathbf{~ m L}^{-\mathbf{1}}$ & Ø $\mathbf{l o g} \mathbf{~ K b e ~} \mathbf{~ m L}^{-\mathbf{1}}$ \\
\hline Petri dish & $1.18 \times 10^{5}$ & 5.05 \\
Glass & $1.07 \times 10^{7}$ & 6.71 \\
Plastic dish (PP ${ }^{*}$ ) & $4.07 \times 10^{6}$ & 6.48 \\
Transparencies (PS $\left.{ }^{* *}\right)$ & $9.62 \times 10^{6}$ & 6.94 \\
Stainless steel & $2.60 \times 10^{1}$ & 1.41 \\
\hline
\end{tabular}

* Polypropylene, ${ }^{* *}$ Polystyrene 


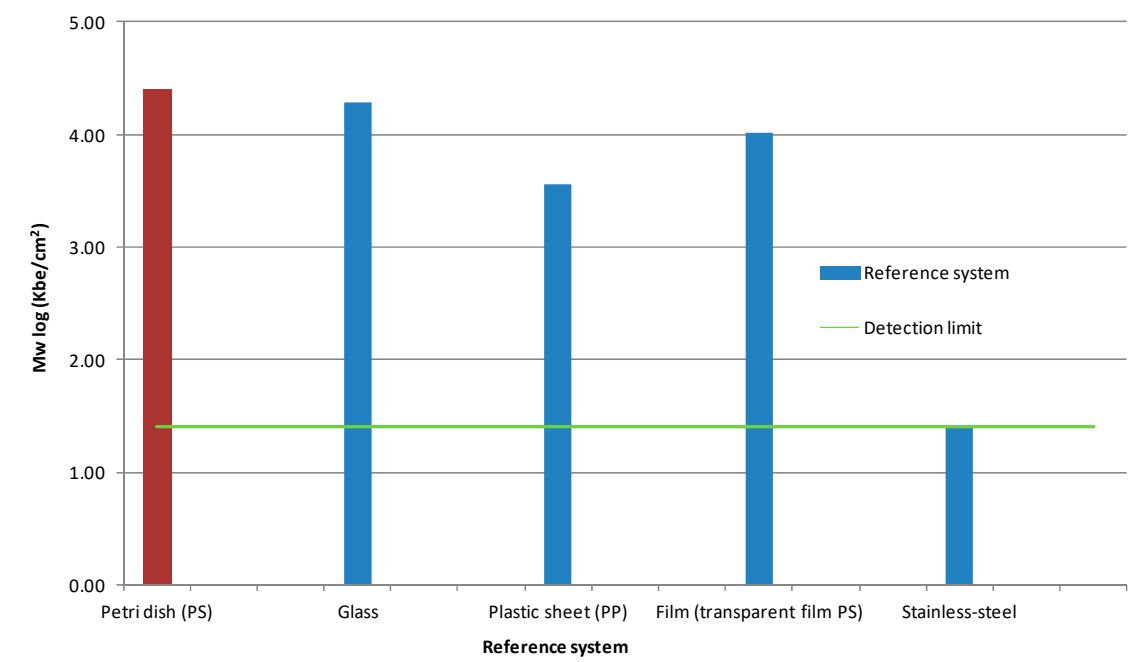

Figure 3. Antimicrobial activity (log Kbe $\mathrm{mL}^{-1}$ ) of different blank surfaces (used as reference systems) against $S$. aureus and Listeria monocytogenes. The green line represents the detection limit for the determination of the antimicrobial activity and is $1.4 \log \left(\mathrm{Kbe} \mathrm{cm}^{-1}\right)$.

As suggested, the results showed normal bacterial growth on blank surfaces: untreated glass, plastic sheets (polypropylene, PP), transparent polystyrene films (PS) and stainless steel (Figure 3). Notable was an emerging germ resistance on the untreated stainless-steel surfaces which underlines the natural antimicrobial effect of stainless-steel surfaces for different bacteria, known as oligodynamic effect. The oligodynamic effects describes the damaging effect of various metal ions on different bacteria, viruses and fungi, most probably due stainless-steel alloy formation initiated by different metal cations [64].

Furthermore, lignin-modified PU coatings prepared from demethylated lignins were applied to various surfaces and analyzed for their antimicrobial action. The results are listed below in Table 4 and Figure 4.

Table 4. Results of antimicrobial activity of demethylated lignin-based polyurethane (PU) coatings against $S$. aureus.

\begin{tabular}{ccc}
\hline Lignin-PU Coatings & Kbe/cm & Ø \\
\hline DL-pH2-060718 & $2.07 \times 10^{3}$ & 3.03 \\
DL-pH3-060718 & $1.17 \times 10^{3}$ & 2.51 \\
DL-pH4-060718 & $3.09 \times 10^{1}$ & 2.36 \\
DL-pH5-060718 & $6.25 \times 10^{-1}$ & 0 \\
\hline
\end{tabular}

The results showed significant microbial reduction against $S$. aureus for the PU coatings synthesized from demethylated lignins. It is also noticeable that the germ reduction can be correlated to the $\mathrm{pH}$ value for lignin isolation: lignins isolated at $\mathrm{pH} 3,4$ and 5 showed a higher germ reduction and antimicrobial activity, respectively, than the reference (blind value: polypropylene glycol (PPG) as polyol without lignin). One reason for this could be the improved homogeneity of the coatings, caused by higher crosslinking density of the LPU due to high $\mathrm{OH}$ numbers, analogous to the correlation of $\mathrm{OH}$ number and antioxidant activity of LPU coatings [29,30]. Besides LPU coatings, it was recently reported that the antimicrobial activity of various lignin-derived cellulose and cellulose/chitosan composites against S. aureus and E. coli (Table 1) [52]. A comparison of hydroxypropylmethyl cellulose/lignin films were blended with Kraft lignin in different amounts up to $30 \mathrm{wt}$.\%. Comparing both systems (HPMC versus $\mathrm{PU}$ ), the capacity against $\mathrm{S}$. aureus was highest for the lignin isolated at $\mathrm{pH} 5$ (Table 5). As supposed, the addition of triphenylmethane derivatives (BG, crystal violet $(\mathrm{CV})$ ) resulted in increased antimicrobial activity against $S$. aureus. 


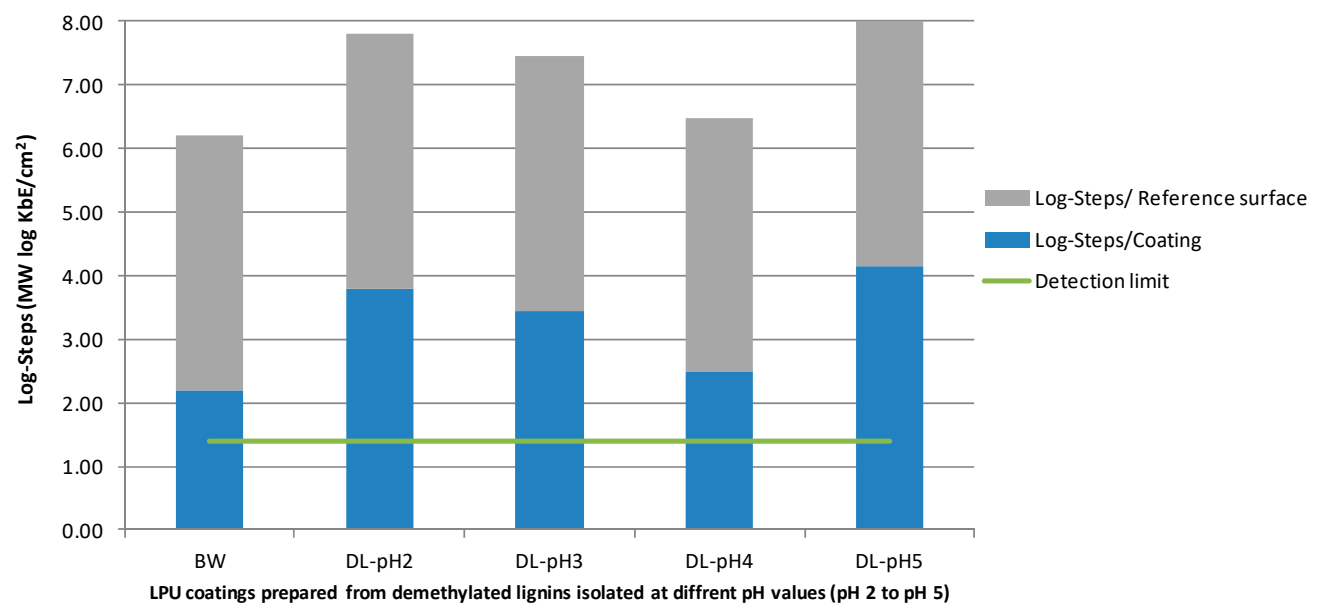

Figure 4. Results of antimicrobial activity against $S$. aureus of lignin-based PU coatings prepared demethylated lignins (DL) isolated at different $\mathrm{pH}$ values ranging from $\mathrm{pH} 2$ to $\mathrm{pH}$ 5. BV:blind value of PU without lignin. The green line represents the detection limit for the determination of the

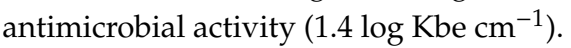

Table 5. Antimicrobial activity of lignin and lignin-derived PU coatings against $S$. aureus. The lignins used for lignin-polyurethane (LPU) coating preparation were isolated from aqueous solution at different $\mathrm{pH}$ values. For comparison, the antimicrobial activity of hydroxypropylmethylcellulose (HPMC)/lignin coatings was added in this table, previously reported in [52].

\begin{tabular}{ccccccc}
\hline $\begin{array}{c}\text { Antimicrobial } \\
\text { Activity }\end{array}$ & $\begin{array}{c}\text { Lignin } \\
\text { (Isolated at } \\
\text { pH 5) }\end{array}$ & $\begin{array}{c}\text { LPU } \\
\text { Coating } \\
\text { (DL-pH5) }\end{array}$ & $\begin{array}{c}\text { LPU } \\
\text { Coating } \\
\text { (KL-pH5) }\end{array}$ & $\begin{array}{c}\text { LPU with } \\
\mathbf{0 . 8} \%(w / v) \\
\text { BG }\end{array}$ & $\begin{array}{c}\text { LPU with } \\
\mathbf{0 . 8} \%(w / v) \\
\text { CV }\end{array}$ & $\begin{array}{c}\text { HPMC/lignin } \\
\text { (15 wt.\% L1) } \\
\text { [52] }\end{array}$ \\
\hline $\begin{array}{c}\log _{10} \\
\text { reduction }\end{array}$ & 7.00 & 4.12 & 2.62 & 8.31 & 8.60 & 2.50 \\
\hline
\end{tabular}

\subsection{Thermal Properties (TGA)}

TGA measurements were performed to describe and evaluate the thermal stability of the corresponding LPU coatings with antimicrobial additives and the coatings prepared from demethylated lignins (Figure 5).

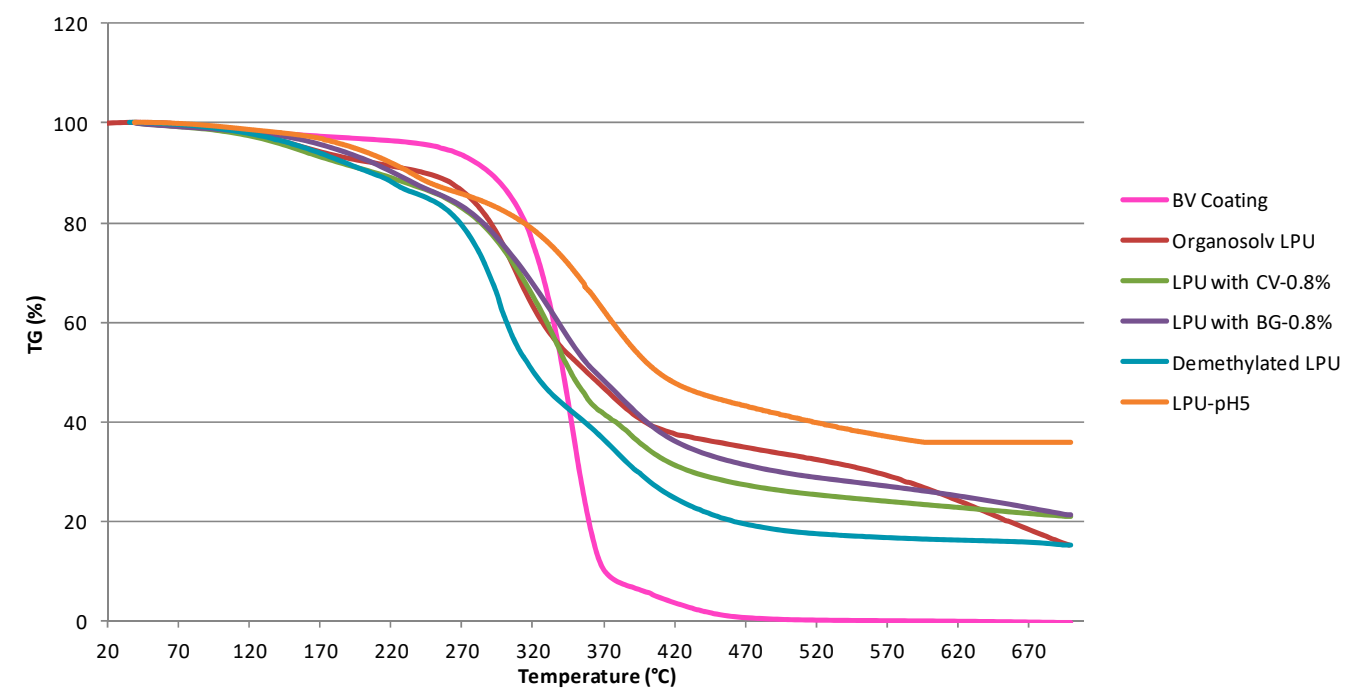

Figure 5. TGA results of different modified lignin-based LPU coatings containing brilliant green (BG) and crystal violet (CV); BV (blind value: PU without lignin). 
TGA results showed thermal stability between $143-165^{\circ} \mathrm{C}$ which are reasonable temperature stabilities for applications in construction and packaging (Table 6). Coatings with $\mathrm{CV}$ as antimicrobial additive showed the highest temperature stability with $165^{\circ} \mathrm{C}$ in contrast to LPU coatings prepared with BG with a stability of $146^{\circ} \mathrm{C}$. The residual mass of both LPU coatings was between $20 \%-21.5 \%$.

Table 6. Thermal stability for lignin and various LPU coatings with/without triphenylmethane (TPM) derivatives.

\begin{tabular}{cccc}
\hline Lignin Coatings & Temperature $\left({ }^{\circ} \mathbf{C}\right)$ & $\boldsymbol{\Delta} \boldsymbol{m}(\mathbf{\%})$ & Residual Mass (\%) \\
\hline Blank (PU coating without lignin) & 250 & $-4.75 \%$ & 0.39 \\
LPU-pH 5 & 166 & $-3.31 \%$ & 35.99 \\
Lignin coating CV & 165 & $-4.05 \%$ & 20.80 \\
Lignin coating BG & 146 & $-4.49 \%$ & 21.43 \\
Lignin coating organosolv & 143 & $-4.03 \%$ & 8.00 \\
Lignin-DLPU coating & 153 & $-4.55 \%$ & 21.43 \\
\hline
\end{tabular}

Obviously, decomposition temperature and residuals are influenced not only by the pulping process used for lignin isolation (Kraft versus organosolv), but also by demethylation and added antimicrobial triphenylmethane derivatives (brilliant green and crystal violet). Further quantification of these effects by DSC measurements is under investigation.

\subsection{Contact Angle of LPU Coatings}

The wettability properties of the surfaces of all lignin-based PUs were investigated by means of static contact angle measurements against water (Table 6). The LPU coatings possessed a rather hydrophobic character with water contact angles $\mathrm{\theta H}_{2} \mathrm{O}$ up to 92 degrees, higher than literature data for LPUs reported by Jia et al. prepared from organosolv lignin $\left(61^{\circ}\right)$. The PU coatings with demethylated lignins showed a contact angle of $84.22 \pm 0.51^{\circ}$. Table 7 summarizes the contact angle data of all LPU with antimicrobial additives. The results revealed that the LPU with brilliant green had a better wettability $\left(87.36 \pm 0.15^{\circ}\right)$ compared to the LPU with crystal violet $\left(67.40 \pm 0.18^{\circ}\right)$.

Table 7. Results of contact angle measurements of the different LPU. Abbreviations: polyurethane (PU), Kraft lignin (KL), organosolv lignin (OL), beech wood (BW), brillant green (BG), crystal violet (CV).

\begin{tabular}{cc}
\hline Sample & Contact Angle $\left.\mathbf{(}^{\circ}\right)$ \\
\hline PU-KL-pH 2 & $92.28 \pm 0.49$ \\
PU-KL-pH 3 & $80.49 \pm 1.03$ \\
PU-KL-pH 4 & $83.28 \pm 0.24$ \\
PU-KL-pH 5 & $86.01 \pm 0.22$ \\
PU-OL & $61,59 \pm 0.69$ \\
PU-KL-Demethylated & $84.22 \pm 0.51$ \\
\hline LPU Coatings with TPM dyes \\
\hline PU-BV-BG & $62.93 \pm 0.34$ \\
PU-BV-CV & $80.19 \pm 0.28$ \\
PU-KL-pH2-BG & $87.36 \pm 0.15$ \\
PU-KL-pH2-CV & $81.11 \pm 0.18$ \\
\hline
\end{tabular}

\subsection{Morphology of the LPU Coatings}

To get a first idea of the homogeneity of the lignin-derived coatings, the coatings were observed via reflected light microscopy showing that homogeneous coatings could be obtained using lignins of number-average molecular weight $\left(M_{\mathrm{n}}\right)<500 \mathrm{~g} / \mathrm{mol}$ (equivalent weight-average $\left(M_{\mathrm{W}}\right)<1570 \mathrm{~g} / \mathrm{mol}$ ) and $\mathrm{OH}$ content above $5 \mathrm{mmol} / \mathrm{g}$ (samples isolated at $\mathrm{pH} 4$ and $\mathrm{pH}$ 5). Using scanning electron microscopy (SEM), the thickness of the casted films was determined to range between 150-160 $\mu \mathrm{m}$ [29].

Figure 6 shows the prepared LPU coatings: (a) with $0.8 \%$ brilliant green added resulted in homogeneous films of greenish color and smooth surface; (b) with $0.8 \%$ crystal violet added also 
resulted in homogeneous films of smooth surface colored in dark blue. Reference coatings are shown containing PU/CV (no lignin) and PU (no lignin, no crystal violet). The antimicrobial activities were determined according to Japanese Industrial Standard (JIS) Z 2801:2010 [59]. Figure 6c shows coatings on different surfaces: stainless steel, wood, plastic (polypropylene). On all surfaces, the coatings showed smooth homogeneous surfaces. In ongoing studies, the adhesion strength will be quantified.

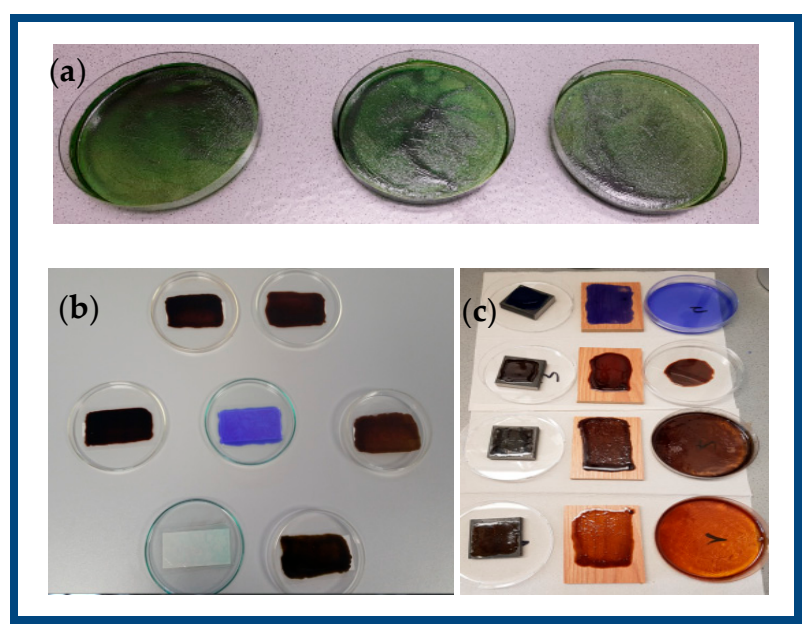

Figure 6. (a) Three lignin-PU coatings with brilliant green as antimicrobial additive; (b) lignin-PU coatings with crystal violet as an antimicrobial additive (blue sample in the middle: PU-CV without lignin; clockwise starting with the white sample (PU without lignin), LPU coatings prepared from organosolv-lignin and lignins isolated at $\mathrm{pH} 2$ to $\mathrm{pH}$ 5; (c) lignin-PU-CV coatings on different surfaces: steel (left), wood (middle) and polystyrene (PS) petri dishes (right); top-down: PU-CV, LPU-CV-pH5, LPU-CV-pH4, LPU-CV-pH2.

\section{Conclusions}

The results of the antimicrobial activity study of lignin-based polyurethane coatings confirmed the capacity of Kraft lignin against special microorganisms such as S. aureus. Triphenylmethane derivatives (brilliant green, crystal violet) significantly increased this antimicrobial effect. The coating color changed from dark brown to green (in case of $\mathrm{BG}$ ) and blue (in case of $\mathrm{CV}$ ). Wettability tests using contact angle measurements confirmed the hydrophobic character of the lignin-derived PU coatings.

Author Contributions: S.E.K. mainly contributed to the manuscript, performed the experiments and analyzed the data; A.A. contributed analytical data regarding the lignins extracted from organic solvents; J.R. contributed in PU coating preparation. I.K. and J.K. contributed antimicrobial analyses; M.S. conceived and designed the experimental studies and contributed in writing the manuscript.

Funding: This research was supported by the Federal Ministry of Education and Research (BMBF) program "IngenieurNachwuchs" project LignoBau (03FH013IX4) and EFRE Infrastrukturförderung "Biobasierte Produkte" (EFRE0500035); Bonn-Rhein-Sieg University/Graduate Institute and Erasmus-Mundus Avempace-II scholarship (A.A.); and Bonn-Rhein-Sieg University/TREE institute (S.E.K.).

Acknowledgments: The authors gratefully acknowledge Zellstoff- und Papierfabrik Rosenthal GmbH (Blankenstein, Germany, MERCER group) for providing the black liquor. We thank Michael Larkins (Raleigh, North Carolina, U.S.) for final English corrections.

Conflicts of Interest: There are no conflicts to declare.

\section{References}

1. Ralph, J.; Lapierre, C.; Boerjan, W. Lignin structure and its engineering. Curr. Opin. Biotechnol. 2019, 56, 240-249. [CrossRef] [PubMed]

2. Rinaldi, R.; Jastrzebski, R.; Clough, M.T.; Ralph, J.; Kennema, M.; Bruijnincx, P.C.A.; Weckhuysen, B.M. Paving the way for lignin valorisation: Recent advances in bioengineering, biorefining and catalysis. Angew. Chem. Int. Ed. 2016, 55, 2-54. [CrossRef] [PubMed] 
3. Alzagameem, A.; El Khaldi-Hansen, B.; Kamm, B.; Schulze, M. Lignocellulosic biomass for energy, biofuels, biomaterials, and chemicals. In Biomass and Green Chemistry, 1st ed.; Vaz, S., Jr., Ed.; Springer International Publishing: Basel, Switzerland, 2018; pp. 95-132.

4. Hansen, B.; Kamm, B.; Schulze, M. Qualitative and quantitative analysis of lignins from different sources and isolation methods for an application as a biobased chemical resource and polymeric material. In Analytical Techniques and Methods for Biomass Products; Vaz, S., Jr., Seidl, P., Eds.; Springer: Berlin, Germany, 2017; pp. $15-44$.

5. Naseem, A.; Tabasum, S.; Zia, K.M.; Zuber, M.; Ali, M.; Noreen, A. Lignin-derivatives based polymers, blends and composites: A review. Int. J. Biol. Macromol. 2016, 93, 296-313. [CrossRef] [PubMed]

6. Ko, F.K.; Goudarzi, A.; Lin, L.-T.; Li, Y.; Kadla, J.F. Lignin-based composite carbon nanofibers. In Lignin in Polymer Composites, 1st ed.; Faruk, O., Sain, M., Eds.; Elsevier B.V: Amsterdam, The Netherlands, 2016; pp. 167-194.

7. Ponomarenko, J.; Dizhbite, T.; Lauberts, M.; Viksna, A.; Dobele, G.; Bikovens, O.; Telysheva, G. Characterization of softwood and hardwood lignoboost kraft lignins with emphasis on their antioxidant activity. Bioresources 2014, 9, 2051-2068. [CrossRef]

8. Benzie, I.F.; Devaki, M. The ferric reducing/antioxidant power (FRAP) assay for non-enzymatic antioxidant capacity: Concepts, procedures, limitations and applications. In Measurement of Antioxidant Activity $\mathcal{E}$ Capacity, 1st ed.; Apak, R., Capanoglu, E., Shahidi, F., Eds.; John Wiley \& Sons Ltd.: Hoboken, NJ, USA, 2017; pp. 77-106.

9. Alzagameem, A.; El Khaldi-Hansen, B.; Büchner, D.; Larkins, M.; Kamm, B.; Witzleben, S.; Schulze, M. Lignocellulosic biomass as source for lignin-based environmentally benign antioxidants. Molecules 2018, 23, 2664. [CrossRef] [PubMed]

10. Bergs, M.; Völkering, G.; Kraska, T.; Do, X.; Monakhova, Y.; Konow, C.; Pude, R.; Schulze, M. Miscanthus $x$ giganteus stem versus leave-derived lignins differing in monolignol ratio and linkage. Int. J. Mol. Sci. 2019, 20, 1200. [CrossRef]

11. Hansen, B.; Kamm, B.; Schulze, M. Qualitative and quantitative analysis of lignin produced from beech wood by different conditions of the Organosolv process. J. Polym. Environ. 2016, 24, 85. [CrossRef]

12. Richter, A.P.; Brown, J.S.; Bharti, B.; Wang, A.; Gangwal, S.; Houck, K.; Cohen Hubal, E.A.; Paunov, V.N.; Stoyanov, S.D.; Velev, O.D. An environmentally benign antimicrobial nanoparticle based on a silver-infused lignin core. Nat. Nanotechnol. 2015, 10, 817-824. [CrossRef]

13. Gregorova, A.; Redik, S.; Sedlarik, V.; Stelzer, F. Lignin-containing polyethylene films with antibacterial activity. In Proceedings of the 3rd International Conference on Thomson Reuters of NANOCON, Brno, Czech Republic, 21-23 September 2011. Available online: http://konference.tanger.cz/data/nanocon2011/ sbornik/lists/papers/1366.pdf (accessed on 5 May 2019).

14. Dai, L.; Liu, R.; Hu, L.-Q.; Zou, Z.-F.; Si, C.-L. Lignin nanoparticle as a novel green carrier for the efficient delivery of resveratrol. ACS Sustain. Chem. Eng. 2017, 5, 8241-8249. [CrossRef]

15. Li, Y.; Yang, D.; Lu, S.; Lao, S.; Qiu, X. Modified lignin with anionic surfactant and its application in controlled release of avermectin. J. Agric. Food Chem. 2018, 66, 3457-3464. [CrossRef]

16. Pang, Y.; Li, X.; Wang, S.; Qiu, X.; Yang, D.; Lou, H. Lignin-polyurea microcapsules with anti-photolysis and sustained-release performances synthesized via pickering emulsion template. React. Funct. Polym. 2018, 123, 115-121. [CrossRef]

17. Wang, Y.; Xiong, Y.; Wang, J.; Zhang, X. Ultrasonic-assisted fabrication of montmorillonite-lignin hybrid hydrogel: Highly efficient swelling behaviors and super-sorbent for dye removal from wastewater. Colloids Surf. A Physicochem. Eng. Asp. 2017, 520, 903-913. [CrossRef]

18. Ciolacu, D.; Oprea, A.M.; Anghel, N.; Cazacu, G.; Cazacu, M. New cellulose-lignin hydrogels and their application in controlled release of polyphenols. Mater. Sci. Eng. C 2012, 32, 452-463. [CrossRef]

19. Kosikova, B.; Labaj, J. Lignin-stimulated protection of polypropylene films and DNA in cells of mice against oxidation damage. Bioresources 2009, 4, 805-815.

20. Gao, Y.; Cranston, R. Recent advances in antimicrobial treatments of textiles. Text. Res. J. 2008, 78, 60-72. [CrossRef]

21. Bshena, O.; Heunis, T.D.; Dicks, L.M.; Klumperman, B. Antimicrobial fibers: Therapeutic possibilities and recent advances. Future Med. Chem. 2011, 3, 1821-1847. [CrossRef] 
22. Gordts, S.C.; Férir, G.; D’huys, T.; Petrova, M.I.; Lebeer, S.; Snoeck, R.; Andrei, G.; Schols, D. The low-cost compound lignosulfonic acid (LA) exhibits broad-spectrum anti-HIV and anti-HSV activity and has potential for microbicidal applications. PLoS ONE 2015, 10, e0131219. [CrossRef]

23. Qiu, M.; Wang, Q.; Chu, Y.; Yuan, Z.; Song, H.; Chen, Z.; Wu, Z. Lignosulfonic acid exhibits broadly anti-HIV-1activity-potential as a microbicide candidate for the prevention of HIV-1 sexual transmission. PLOS ONE 2012, 7, e35906. [CrossRef]

24. Kai, D.; Tan, M.J.; Chee, P.L.; Chua, Y.K.; Yap, Y.L.; Loh, X.J. Towards lignin-based functional materials in a sustainable world. Green Chem. 2016, 18, 1175-1200. [CrossRef]

25. Lau, P.C.K. Lignin: A platform for renewable aromatic polymeric materials. In Quality Living Through Chemurgy and Green Chemistry. Green Chemistry and Sustainable Technology; Lau, P.C.K. Springer: Berlin/Heidelberg, Germany, 2016; pp. 221-263.

26. Ten, E.; Vermerris, W. Recent developments in polymers derived from industrial lignin. J. Appl. Polym. Sci. 2015, 132, 1-13. [CrossRef]

27. Jia, Z.; Lu, C.; Zhou, P.; Wang, L. Preparation and characterization of high boiling solvent lignin-based polyurethane film with lignin as the only hydroxyl group provider. RSC Adv. 2015, 5, 53949-53955. [CrossRef]

28. Griffini, G.; Passoni, V.; Suriano, R.; Levi, M.; Turri, S. Polyurethane coatings based on chemically unmodified fractionated lignin. ACS Sustain. Chem. Eng. 2015, 3, 1145-1154. [CrossRef]

29. Klein, S.E.; Rumpf, J.; Kusch, P.; Albach, R.; Rehahn, M.; Witzleben, S.; Schulze, M. Utilization of unmodified kraft lignin for the preparation of highly flexible and transparent polyurethane coatings. RSC Adv. 2018, 8, 40765. [CrossRef]

30. Klein, S.E.; Rumpf, J.; Rehahn, M.; Witzleben, S.; Schulze, M. Biobased flexible polyurethane coatings prepared from kraft lignin: One-pot synthesis and antioxidant activity. J. Coat. Technol. Res. 2019. [CrossRef]

31. Hu, J.; Zhang, Q.; Lee, D.-J. Kraft lignin biorefinery: A proposal. Bioresour. Technol. 2017, 247, 1181-1183. [CrossRef]

32. Sain, M.; Faruk, O. Lignin in Polymer Composites, 1st ed.; Elsevier: Kidlington, UK, 2016.

33. Li, J.; Wang, W.; Shifeng, Z.; Qiang, G.; Zhang, W.; Li, J. Preparation and characterization of lignin demethylated at atmospheric pressure and its application in fast curing biobased phenolic resins. RSC Adv. 2016, 6, 67435-67443. [CrossRef]

34. Laurichesse, S.; Avérous, L. Chemical modification of lignins: Towards biobased polymers. Prog. Polym. Sci. 2014, 39, 1266-1290. [CrossRef]

35. Chung, H.; Washburn, N.R. Improved lignin polyurethane properties with Lewis acid treatment. ACS Appl. Mater. Interfaces 2012, 4, 2840-2846. [CrossRef]

36. Zou, L.; Ross, B.M.; Hutchison, L.J.; Christopher, L.P.; Dekker, R.F.; Malek, L. Fungal demethylation of Kraft lignin. Enzyme Microb. Technol. 2015, 73-74, 44-50. [CrossRef]

37. Ibrahim, V.; Mendoza, L.; Mamo, G.; Hatti-Kaul, R. Blue laccase from Galerina sp.: Properties and potential for Kraft lignin demethylation. Process Biochem. 2011, 46, 379-384. [CrossRef]

38. Song, Y.; Wang, Z.; Yan, N.; Zhang, R.; Li, J. Demethylation of wheat straw alkali lignin for application in phenol formaldehyde adhesives. Polymers 2016, 8, 209. [CrossRef]

39. An, X.; Schroeder, H.A.; Thompson, G.E. Demethylated kraft lignin as a substitute for phenol in wood adhesive. Chem. Ind. For. Prod. 1995, 15, 36-42.

40. Ferhan, M.; Sain, M.; Yan, N. A new method for demethylation of lignin from woody biomass using biophysical methods. J. Chem. Eng. Process. Technol. 2013, 4, 160. [CrossRef]

41. Podschun, J.; Saake, B.; Lehnen, R. Catalytic demethylation of organosolv lignin in aqueous medium using indium triflate under microwave irradiation. React. Funct. Polym. 2017, 119, 82-86. [CrossRef]

42. Webb, C.H.S. A note on the value of brilliant green as an antiseptic. Br. Med. J. 1917, 1, 870. [CrossRef]

43. Sneader, W. Drug Discovery: A history; John Wiley and Sons Ltd.: Chichester, UK, 2005; p. 468.

44. Schirmer, R.H.; Coulibaly, B.; Stich, A.; Scheiwein, M.; Merkle, H.; Eubel, J.; Becker, K.; Becher, H.; Müller, O.; Zich, T.; et al. Methylene blue as an antimalarial agent. Redox Rep. 2003, 8, 272-275. [CrossRef]

45. Boulos, R. Bacterial Mechanosensitive Channels as Novel Targets for Antibacterial Agents. Ph.D. Thesis, The University of Western Australia, Perth, Australia, December 2011.

46. Boulos, R.A. Antimicrobial Compounds. U.S. Patent 20120329871 A1, 27 December 2012.

47. Boulos, R.A.; Eroglu, E.; Chen, X.; Scaffidi, A.; Edwards, B.R.; Toster, J.; Raston, C.L. Unravelling the structure and function of human hair. Green Chem. 2013, 15, 1268-1273. [CrossRef] 
48. Vilela, S.F.G.; Junqueira, J.C.; Barbosa, J.O.; Majewski, M.; Munin, E.; Jorge, A.O.C. Photodynamic inactivation of Staphylococcus aureus and Escherichia coli biofilms by malachite green and phenothiazine dyes: An in vitro study. Arch. Oral Biol. 2012, 57, 704-710. [CrossRef]

49. Noimark, S.; Allan, E.; Parkin, I.P. Light-activated antimicrobial surfaces with enhanced efficacy induced by a dark-activated mechanism. Chem. Sci. 2014, 5, 2216. [CrossRef]

50. Bartoszewicz, L. Antimicrobial Photo-Stable Coating Composition. WO2009015476A1, 5 February 2009.

51. Santos, M.R.E.; Fonseca, A.C.; Mendonça, P.V.; Branco, R.; Serra, A.C.; Morais, P.V.; Coelho, J.F.J. Recent developments in antimicrobial polymers: A review. Materials 2016, 9, 599. [CrossRef]

52. Alzagameem, A.; Klein, S.E.; Bergs, M.; Do, X.T.; Korte, I.; Dohlen, S.; Kreyenschmidt, J.; Kamm, B.; Larkins, M.; Schulze, M. Antimicrobial activity of lignin and lignin-derived cellulose and chitosan composites against selected pathoge nic and spoilage microorganisms. Polymers 2019, 11, 670. [CrossRef]

53. Yang, W.; Fortunati, E.; Dominici, F.; Giovanale, G.; Mazzaglia, A.; Balestra, G.M.; Kenny, J.M.; Puglia, D. Effect of cellulose and lignin on disintegration, antimicrobial and antioxidant properties of PLA active films. Int. J. Biol. Macromol. 2016. [CrossRef]

54. Kaur, R.; Uppal, S.K.; Sharma, P. Antioxidant and antibacterial activities of sugarcane bagasse lignin and chemically modified lignins. Sugar Tech. 2017, 19, 675-680. [CrossRef]

55. Witzler, M.; Alzagameem, A.; Bergs, M.; El Khaldi-Hansen, B.; Klein, S.E.; Hielscher, D.; Kamm, B.; Kreyenschmidt, J.; Tobiasch, E.; Schulze, M. Lignin-derived biomaterials for drug release and tissue engineering. Molecules 2018, 23, 1885. [CrossRef]

56. Monakhova, Y.; Diehl, B.W.K.; Do, X.T.; Witzleben, S.; Schulze, M. Novel method for the determination of average molecular weight of natural polymers based on 2D DOSY NMR and chemometrics: Example of heparin. J. Pharm. Biomed. Anal. 2018, 149, 128-132. [CrossRef]

57. Alzagameem, A.; Bergs, M.; Do, X.T.; Klein, S.E.; Rumpf, J.; Larkins, M.; Monakhova, Y.; Pude, R.; Schulze, M. Low-input crops as lignocellulosic feedstock for second generation biorefineries and the potential of chemometrics in biomass quality control. Appl. Sci. 2019, 9, 2252. [CrossRef]

58. Garcia, A.; Toledano, A.; Serrano, A.; Egüés, I.; González, M.; Marín, F.; Labidi, J. Characterization of lignins obtained by selective precipitation. Sep. Purif. Technol. 2009, 68, 193-198. [CrossRef]

59. Japanese Industrial Standard. Z 2801:2000. ICS 07.100.10; 11.100 Descriptors: Bacteriocide-Activity Determination, Microbiological-Resistance Tests, Biological Hazards, Culture Techniques. Available online: http://lotusyapi.com.tr/Antibacterial/JIS\%20Z\%202801\%202000.pdf (accessed on 5 May 2019).

60. Pan, X.; Saddler, J.N. Effect of replacing polyol by organosolv and kraft lignin on the property and structure of rigid polyurethane foam. Biotechnol. Biofuels 2013, 6, 12-21. [CrossRef]

61. Tavares, L.B.; Boas, C.V.; Schleder, G.R.; Nacas, A.M.; Rosa, D.S.; Santos, D.J. Bio-based polyurethane prepared from Kraft lignin and modified castor oil. eXPRESS Pol. Lett. 2016, 10, 927-940. [CrossRef]

62. Dohlen, S.; Braun, C.; Brodkorb, F.; Fischer, B.; Ilg, Y.; Kalbfleisch, K.; Kreyenschmidt, M.; Lorenz, R.; Kreyenschmidt, J. Effect of different packaging materials containing poly-[2-(tert-butylamino) methylstyrene] on the growth of spoilage and pathogenic bacteria on fresh meat. Int. J. Food Microbiol. 2017, 257, 91-100. [CrossRef]

63. Dohlen, S.; Braun, C.; Brodkorb, F.; Fischer, B.; Ilg, Y.; Kalbfleisch, K.; Kreyenschmidt, M.; Lorenz, R.; Robers, O.; Kreyenschmidt, J. Potential of the polymer poly-[2-(tert-butylamino) methylstyrene] as antimicrobial packaging material for meat products. J. Appl. Microbiol. 2016, 4, 1059-1070. [CrossRef]

64. Hüwe, C.; Schmeichel, J.; Brodkorb, F.; Dohlen, S.; Kalbfleisch, K.; Kreyenschmidt, M.; Lorenz, R.; Kreyenschmidt, J. Potential of antimicrobial treatment of linear low-density polyethylene with poly((tert-butyl-amino)-methyl-styrene) to reduce biofilm Formation in the Food industry. Biofouling 2018, 34, 378-387. [CrossRef]

65. Braun, C.; Dohlen, S.; Ilg, Y.; Brodkorb, F.; Fischer, B.; Heindirk, P.; Kalbfleisch, K.; Richter, T.; Robers, O.; Kreyenschmidt, M. Antimicrobial activity of intrinsic antimicrobial polymers based on poly((tertbutyl-amino)-methyl-styrene) against selected pathogenic and spoilage microorganisms relevant in meat processing facilities. J. Antimicrob Agents 2017, 3, 1000136. [CrossRef]

66. Song, W.; Ge, S. Application of antimicrobial nanoparticles in dentistry. Molecules 2019, 24, 1033. [CrossRef]

(C) 2019 by the authors. Licensee MDPI, Basel, Switzerland. This article is an open access article distributed under the terms and conditions of the Creative Commons Attribution (CC BY) license (http://creativecommons.org/licenses/by/4.0/). 